\title{
Fish community of a small, temperate, urban river in South Africa
}

\author{
C Muller', NA Strydom ${ }^{* 1}$ and OLF Wey| $\left.\right|^{2,3}$ \\ 'Zoology Department, PO Box 77000, Nelson Mandela Metropolitan University, Port Elizabeth 6031, South Africa \\ ${ }^{2} S o u t h$ African Institute for Aquatic Biodiversity (SAIAB), Private Bag 1015, Grahamstown 6140, South Africa \\ ${ }^{3}$ Centre for Invasion Biology, SAIAB, Private Bag 1015, Grahamstown 6140, South Africa
}

\begin{abstract}
Freshwater and marine-spawned fishes were sampled from the Baakens River, a small urban river that runs through the city of Port Elizabeth in the Eastern Cape of South Africa. Using fyke nets, 8 sites were sampled along the river course over a 4-month period (January - April 2014). Catches were comprised of indigenous freshwater, marine migrant and alien fishes. Marine migrant fishes, including catadromous species dependent on freshwater for early life-history strategies, were significantly affected by instream barriers which prohibited upstream migration of all species except Anguilla mossambica. The freshwater fish fauna was dominated by Tilapia sparrmanii and Pseudocrenilabrus philander, species that are alien to the Baakens River. While indigenous Barbus pallidus and Sandelia capensis were both abundant and widely distributed in the river, only two Pseudobarbus afer were sampled from one survey site. The low abundance and narrow distribution of this endangered species is of concern and human-mediated impacts on this species require urgent evaluation and mitigation.
\end{abstract}

Keywords: Baakens River, migration barrier, weir, alien fish, endangered fish

\section{INTRODUCTION}

South Africa is a water-stressed country and rivers and lakes are critical for providing freshwater for human use (Mukheibir and Sparks, 2003). As a consequence, many rivers and their basins have been altered for the purposes of water provisioning, with little concern for dependent ecosystems. Freshwater fishes are entirely dependent on these habitats for their existence and survival and their dependence renders them extremely vulnerable to anthropogenic influence in the form of habitat alteration, degradation of water quality and barriers (Skelton et al., 1995). Worldwide, the fragmentation of river systems has been suggested as the primary factor leading to the decline in migratory fish populations (Masters et al., 2006). Furthermore, the dynamic longitudinal nature of river systems means that point-source impacts are transmitted downstream for distances proportional to the scale and nature of the impact (Skelton et al., 1995).

Human-mediated impacts on rivers in South Africa include habitat alteration, freshwater abstraction and the introduction of alien species which have been identified as primary contributors to the decline in native fish populations, particularly in the Cape Fold ecoregion in South Africa where endemic species have limited distribution ranges (Darwall et al., 2009). In addition, changes to freshwater inputs and flow regimes have been shown to result in a decline in the diversity and abundance of fishes in estuarine regions (Plumstead, 1990), and river fragmentation resulting from the construction of instream barriers (Geeraerts et al., 2007) prevents migration of freshwater-dependent marine species (Wasserman et al., 2011). Urban rivers are particularly vulnerable to this suite of anthropogenically-induced threats.

\footnotetext{
* To whom all correspondence should be addressed.

E-mail: Nadine.Strydom@nmmu.ac.za

Received: 5 December 2014; accepted in revised from 9 October 2015
}

The current study endeavours to provide information on the composition, distribution and abundance of freshwater and marine-spawned fishes in the Baakens River, a small (23 km long), urban river in the Eastern Cape of South Africa that rises and falls within the City of Port Elizabeth (Muller et al., 2015). The river course runs through the city centre and has been widely altered from its original state by the construction of instream barriers and the introduction of alien fishes (Muller et al., 2015). The Baakens River is a National Freshwater Ecosystem Priority Area (NFEPA) and has been listed as a 'fish sanctuary' primarily due to the presence of the endangered Eastern Cape redfin Pseudobarbus afer (Peters, 1864) (Nel et al., 2011). The primary aim of the current study was to determine the composition, abundance and distribution of fishes currently resident in the Baakens River and to determine the extent of migration restriction by instream barriers for marine-spawned fishes.

\section{MATERIALS AND METHODS}

\section{Study area}

The Baakens River (Fig. 1) is a short perennial urban river with a small catchment of approximately $20 \mathrm{~km}^{2}$. The river runs through a narrow valley for approximately $23 \mathrm{~km}$, through the city of Port Elizabeth in a west to east orientation, and terminates at the Port Elizabeth harbour. The region has a temperate climate with average temperatures ranging from $18-25^{\circ} \mathrm{C}$ in summer and $9-20^{\circ} \mathrm{C}$ in winter. Rainfall follows a bimodal pattern with peaks in spring and autumn and a wide variation between years ranging from $350-1200 \mathrm{~mm}$ (Lear, 2013). To alleviate the risk of flooding, the region near the river mouth was canalised in 1897, where it originally formed a lagoon (Lear, 2013). In a survey of instream barriers, Bok (1997) identified 5 causeways within the lower $6 \mathrm{~km}$ of the river, all of which are potential barriers to upstream movement. 


\section{Field sampling}

Field sampling was conducted on the Baakens River with the first sampling site at the river mouth, and the last approximately $15 \mathrm{~km}$ upstream (Fig. 1). Within this sampling area there are numerous manmade obstacles to fish migration, including 5 causeways and 2 high weirs. Eight (8) fixed sampling sites were selected (Table 1) along the length of the river and sampled monthly for 4 consecutive months (January - April 2014) to include summer recruitment and immigration of marine-spawned species using a double-winged, fine-meshed $(2 \mathrm{~mm})$ fyke net. All fyke nets were fitted with an otter guard comprising plastic mesh with openings of $45 \mathrm{~mm}$ $\times 45 \mathrm{~mm}$. While the use of otter guards is essential to avoid bycatch and subsequent drowning of the Cape clawless otter Aonyx capensis, their use limits the maximum size of fish sampled in the fyke nets to fish smaller than the aperture of the guard net and therefore excludes adults of some larger fish species e.g., Micropterus salmoides and Cyprinus carpio. Fyke nets were set along the river margins facing downstream. All nets were set before sunset and retrieved shortly after sunrise the following day. Soak times were recorded for each net. On retrieval, all fish caught were identified to species and measured to the nearest millimetre total length (TL). All catches were expressed as catch per unit effort which refers to the total number of fish caught per hour. This was derived from the total number of individuals caught during the total soak time, in hours, for each net on each sampling occasion. Using a YSI 6600 multi-parameter probe, temperature $\left({ }^{\circ} \mathrm{C}\right)$, total dissolved solids (TDS), salinity (PSU), $\mathrm{pH}$, conductivity (ms/ $\mathrm{cm}^{3}$ ) and dissolved oxygen (\%) were measured at each site on each occasion.

\begin{tabular}{|l|c|c|}
\hline \multicolumn{3}{|c|}{ TABLE 1 } \\
Location of study sites and distance from river mouth \\
\hline Site & Location & Distance $(\mathbf{k m})$ \\
\hline 1 & $33^{\circ} 57^{\prime} 53^{\prime \prime} \mathrm{S} ; 25^{\circ} 37^{\prime} 30^{\prime \prime} \mathrm{E}$ & 0.17 \\
\hline 2 & $33^{\circ} 58^{\prime} 10^{\prime \prime} \mathrm{S} ; 25^{\circ} 37^{\prime} 02^{\prime \prime} \mathrm{E}$ & 1.17 \\
\hline 3 & $33^{\circ} 58^{\prime} 15^{\prime \prime} \mathrm{S} ; 25^{\circ} 36^{\prime} 47^{\prime \prime} \mathrm{E}$ & 1.59 \\
\hline 4 & $33^{\circ} 58^{\prime} 16^{\prime \prime} \mathrm{S} ; 25^{\circ} 36^{\prime} 14^{\prime \prime} \mathrm{E}$ & 2.47 \\
\hline 5 & $33^{\circ} 58^{\prime} 09^{\prime \prime} \mathrm{S} ; 25^{\circ} 34^{\prime} 47^{\prime \prime} \mathrm{E}$ & 6.47 \\
\hline 6 & $33^{\circ} 57^{\prime} 30^{\prime \prime} \mathrm{S} ; 25^{\circ} 33^{\prime} 36^{\prime \prime} \mathrm{E}$ & 9.73 \\
\hline 7 & $33^{\circ} 57^{\prime} 17^{\prime \prime} \mathrm{S} ; 25^{\circ} 32^{\prime} 44^{\prime \prime} \mathrm{E}$ & 12.70 \\
\hline 8 & $33^{\circ} 57^{\prime} 39^{\prime \prime} \mathrm{S} ; 25^{\circ} 31^{\prime} 21^{\prime \prime} \mathrm{E}$ & 15.40 \\
\hline
\end{tabular}

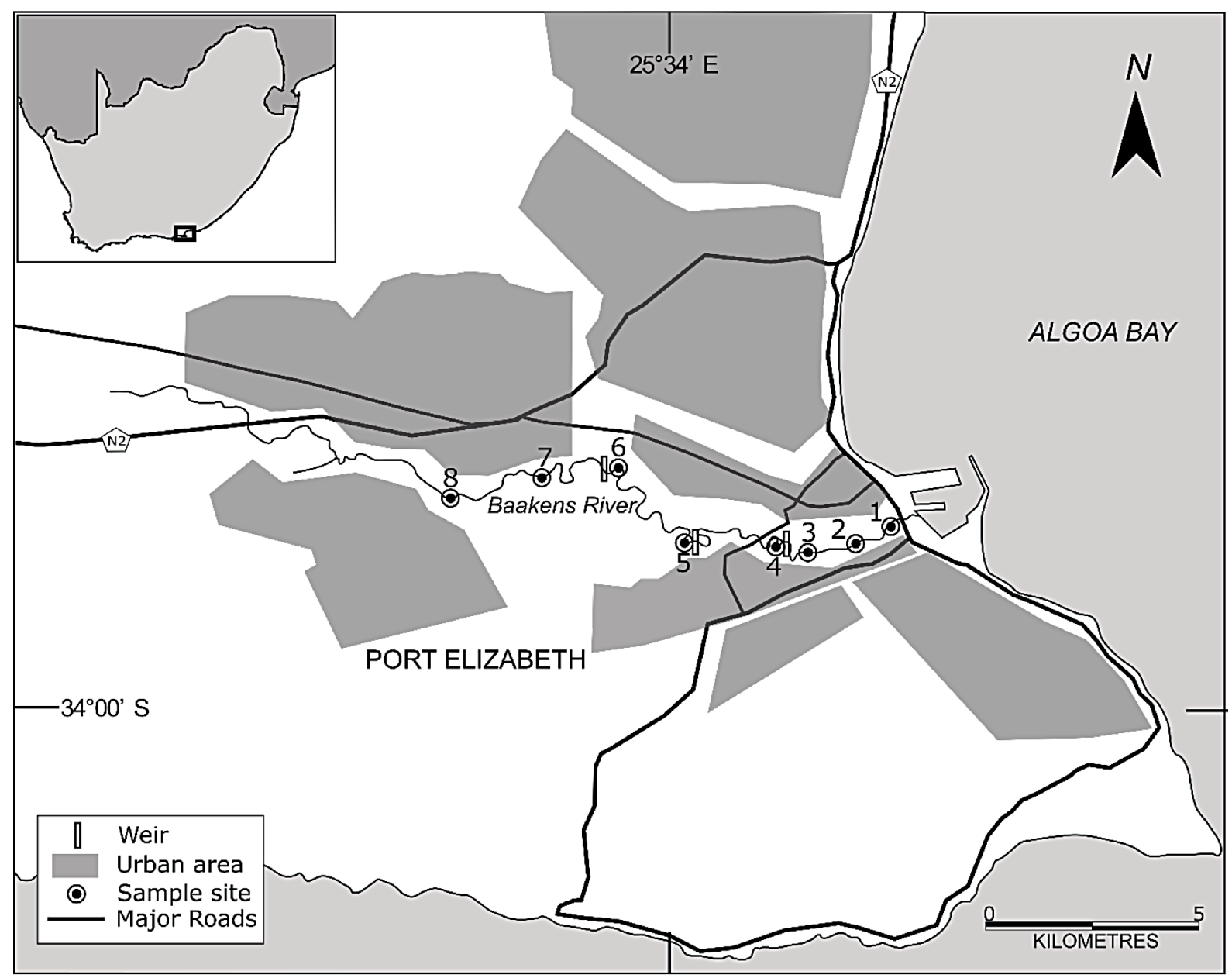

Figure 1

Geographic position of the Baakens River showing location of sampling sites and location of barriers as vertical bars 


\section{Data analysis}

Normality and homogeneity of variance tests were completed for physical and biological data, using a Shapiro-Wilk test and normal probability plots. CPUE and physical data did not conform to test assumptions and therefore non-parametric tests were used for all analysis. Physical parameters were tested among sites using the non-parametric Kruskal-Wallis test. A Spearman Rank Correlation test was used to test for relationships between CPUE and physico-chemical parameters.

PRIMER statistical software package V6.1.16 was used to assess current community trends and to calculate diversity indices, namely, Margalef's species richness $(d)$ and Shannon-Wiener diversity $\left(H^{\prime}\right)$. These were compared among sites and particularly with regard to barrier location. Biological data were square-root transformed prior to analyses. No differentiation was made between catadromous, marine-spawned and estuary-dependent or resident species; all species were grouped and referred to as marine migrants due to their low average abundance. The SIMPER routine was performed to determine the relative contribution of key species to the similarity among sites along the river course. To assess the effects of barriers on the migration of marine migrant species, the dominant, uniformly distributed alien species were removed from the cluster analysis. A further SIMPER routine was performed excluding all alien species to determine the effects that barriers had on the indigenous community. A significance level of $P<0.05$ was used for all statistical analysis.

\section{RESULTS}

\section{Environmental variability}

The physical variables measured over the study period are summarised in Fig. 2. Temperature, TDS, salinity, $\mathrm{pH}$ and conductivity did not differ significantly between sites but varied temporally. Water temperature ranged from a maximum of $29.9^{\circ} \mathrm{C}$ in January to a minimum of $15.3^{\circ} \mathrm{C}$ in April. Mean TDS declined from January (0.92) through to April (0.72); as did salinity $(0.71-0.55)$. The $\mathrm{pH}$ (mean 6.63 ) remained stable throughout the sampling period. Despite Site 1 being located within the tidal influence of the Baakens River Estuary there appeared to be no saltwater intrusion from the ocean during the study period as salinity units were never higher than 1 PSU.
Dissolved oxygen levels did not vary greatly throughout the sampling period but low levels were regularly recorded at Site 5 above the Dodd's Farm Weir. The reservoir above the weir is a collection point for debris and sediment and a strong smell of sulphur dioxide was regularly noted at this location.

\section{Community composition}

A total of 5118 fish, representing 8 families and 11 species, were sampled during the study (Table 2). Marine-spawned species Anguilla mossambica (Peters, 1852), Awaous aenofuscus (Peters, 1852), Eleotris fusca (Forster, 1801), Myxus capensis (Valenciennes, 1836), Monodactylus falciformis Lacepède, 1801, and a goby Stenogobius sp. that could not be identified to species level, represented 6 of the 11 species sampled but only accounted for just over $2 \%$ of the number of fish sampled. Indigenous freshwater fishes: Barbus pallidus Smith, 1841, Pseudobarbus afer and Sandelia capensis (Cuvier, 1829), contributed 22\% while 2 species alien to the Baakens River, Pseudocrenilabrus philander (Weber, 1897) and Tilapia sparrmanii Smith, 1840, accounted for $75 \%$ of the number of fish sampled.

Barbus pallidus and S. capensis were present along most of the river course but were more abundant in the upper reaches above Site 5. All marine-spawned species were restricted to the lower region between Site 1 and Site 3, except for A. mossambica which was also sampled from Site 5. Pseudocrenilabrus philander and T. sparrmanii were the only ubiquitous species. SIMPER analysis revealed that these two alien species were the dominant contributing species to similarity between sites, $P$. philander contributed approximately $34 \%$ to the similarity among all sites studied while T. sparrmanii contributed $28 \%$.

\section{Spatial trends in species diversity and abundance}

An overall species richness $(d)$ and species diversity $\left(H^{\prime}\right)$ value of 1.1 was obtained for the Baakens River. Species richness and diversity were higher near the mouth (Site 1) where mean values of $d=1.4$ and $H^{\prime}=1.2$ were obtained. A simple linear regression was calculated to predict species richness $(d)$ based on distance from mouth (site). A weak regression relationship $(P<0.05)$ was found $(F(1,29)=4.99)$, with an adjusted $R^{2}$ of 0.118 and $r=-0.383$ (Fig. 3). Species richness decreased moving upstream with Site $7(d=0.8)$ having the lowest richness.

TABLE 2

Species composition, CPUE, length and percentage composition of total catch by number (\%) in the Baakens River (January - April 2014)

\begin{tabular}{|c|c|c|c|c|c|c|}
\hline Family & Species & Common name & $\begin{array}{c}\text { Mean CPUE } \\
\text { (Range) fish/hr }\end{array}$ & $\begin{array}{c}\text { Mean length } \\
\text { (range) mm (TL) }\end{array}$ & $\begin{array}{c}\text { Total } \\
\text { captured }\end{array}$ & $\begin{array}{c}\text { Catch } \\
\text { composition \% }\end{array}$ \\
\hline Anabantidae & Sandelia capensis & Cape kurper & $13.50(0-70)$ & $72.80(22-158)$ & 162 & 3.27 \\
\hline Anguillidae & Anguilla mossambica & Longfin eel & $0.42(0-1)$ & $364.00(89-690)$ & 5 & 0.10 \\
\hline \multirow[t]{2}{*}{ Cichlidae } & $\begin{array}{l}\text { Pseudocrenilabrus } \\
\text { philander }\end{array}$ & $\begin{array}{l}\text { Southern } \\
\text { mouthbrooder }\end{array}$ & $155.42(0-317)$ & $50.50(7-109)$ & 1865 & 36.44 \\
\hline & Tilapia sparrmanii & Banded tilapia & $166.08(0-888)$ & $67.70(5-140)$ & 1993 & 38.94 \\
\hline \multirow[t]{2}{*}{ Cyprinidae } & Barbus pallidus & Goldie barb & $82.08(0-267)$ & $42.80(17-63)$ & 985 & 19.25 \\
\hline & Pseudobarbus afer & Eastern Cape redfin & $0.16(0-1)$ & $51.50(49-54)$ & 2 & 0.04 \\
\hline Eleotridae & Eleotris fusca & Dusky sleeper & $0.16(0-1)$ & 50 & 2 & 0.04 \\
\hline \multirow[t]{2}{*}{ Gobiidae } & Awaous aenofuscus & Freshwater goby & $0.16(0-1)$ & $180.00(165-210)$ & 2 & 0.04 \\
\hline & Stenogobius sp. & Unidentified goby & $0.08(0-1)$ & 70 & 1 & 0.02 \\
\hline Monodactylidae & Monodactylus falciformis & Cape moony & $3.42(0-9)$ & $64.50(32-114)$ & 41 & 0.80 \\
\hline Mugilidae & Myxus capensis & Freshwater mullet & $3.42(0-13)$ & $65.20(27-113)$ & 41 & 0.80 \\
\hline
\end{tabular}



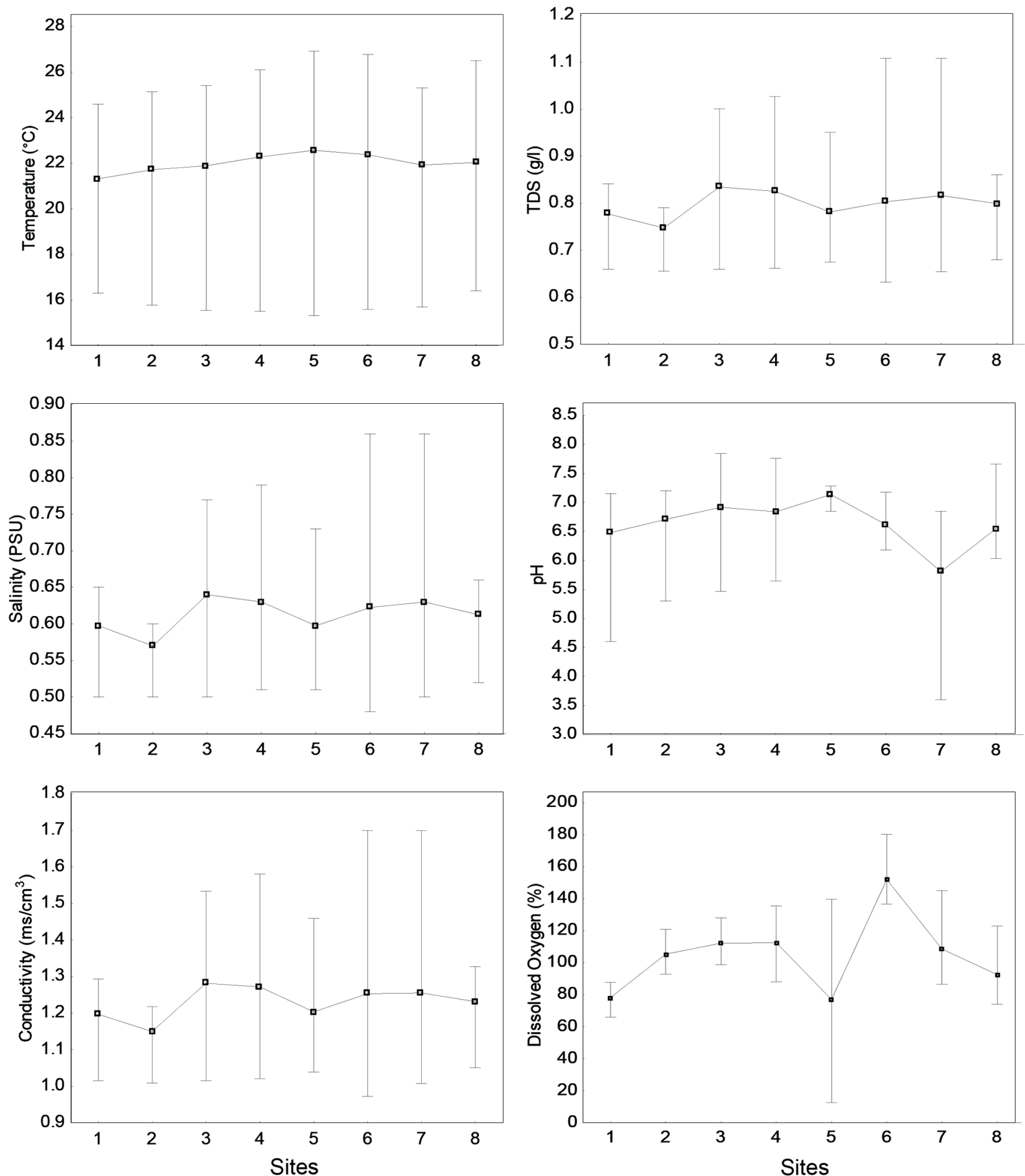

Figure 2

Mean temperature $\left({ }^{\circ} \mathrm{C}\right)$, total dissolved solids (TDS, g/ $)$, salinity (PSU), $\mathrm{pH}$, conductivity $\left(\mathrm{ms} / \mathrm{cm}^{3}\right)$, and dissolved oxygen (\% saturation) at each site within the Baakens River recorded from January - April 2014. Bars indicate range. 


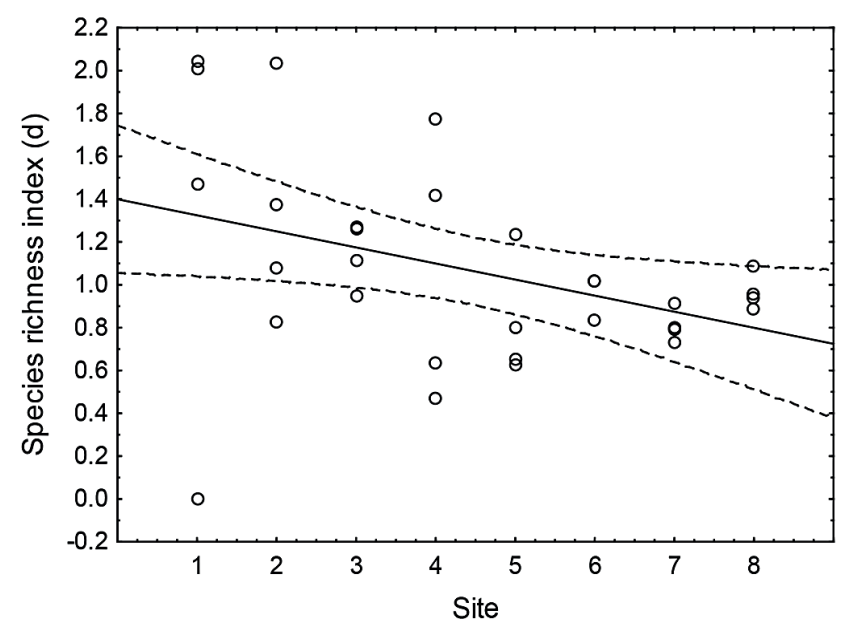

Figure 3

Species richness index (d) for all sampling events and sites displaying decline in species richness in upstream direction

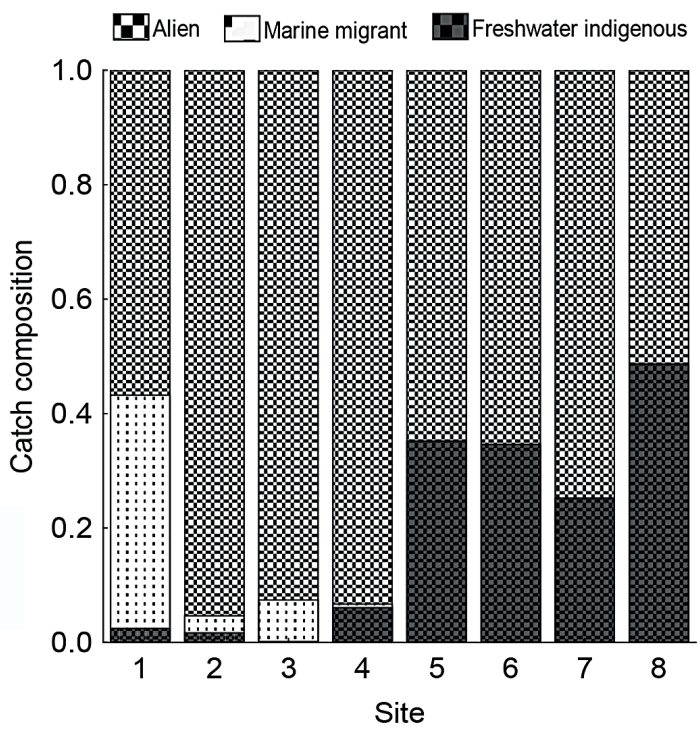

Figure 4

Catch composition at each site for alien, indigenous freshwater and marine migrant groups

\begin{tabular}{|c|c|c|c|c|c|c|c|c|}
\hline \multirow[t]{2}{*}{ Species } & \multicolumn{8}{|c|}{ Sites } \\
\hline & 1 & 2 & 3 & 4 & 5 & 6 & 7 & 8 \\
\hline \multicolumn{9}{|l|}{ Anguilla mossambica } \\
\hline \multicolumn{9}{|l|}{ Monodactylus falciformis } \\
\hline \multicolumn{9}{|l|}{ Myxus capensis } \\
\hline \multicolumn{9}{|l|}{ Awaous aenofuscus } \\
\hline \multicolumn{9}{|l|}{ Eleotris fusca } \\
\hline \multicolumn{9}{|l|}{ Barbus pallidus } \\
\hline \multicolumn{9}{|l|}{ Pseudobarbus afer } \\
\hline \multicolumn{9}{|l|}{ Sandelia capensis } \\
\hline \multicolumn{9}{|l|}{ Stenogobius sp. } \\
\hline \multicolumn{9}{|l|}{ Pseudocrenilabrus philander } \\
\hline Tilapia sparrmanii & & & & & & & & \\
\hline
\end{tabular}

Figure 5

Overall presence and absence of all species per site collected in the Baakens River (January - April 2014)
Species diversity similarly showed a declining trend moving upstream, with average $H^{\prime}=1.2$ near the mouth compared to $H^{\prime}=1.0$ in the upper regions.

Average CPUE varied considerably between sites but generally increased moving upstream. CPUE was consistently lowest at the river mouth (Site 1) and increased to approximately $20 \mathrm{fish} / \mathrm{h}$ at Site 3 and remained consistent up to Site 7 where CPUE was generally higher (up to $160 \mathrm{fish} / \mathrm{h}$ on one occasion). Marine migrants made up a small proportion of the catch composition and were limited to the lower sites. Throughout the Baakens River the alien species $P$. philander and T. sparrmanii accounted for more than $50 \%$ of the total catch while indigenous freshwater fish species made a smaller contribution of approximately $3 \%$ in the lower reaches and 30\% in upper reaches (Fig. 4).

\section{Barrier effects}

Sites 1,2 and 3 (lower $2.2 \mathrm{~km}$ ) are separated from Site 4 by the $\pm 2 \mathrm{~m}$ high Holland weir, which is separated from Site 5 by the $\pm 3 \mathrm{~m}$ high Dodd's Farm weir. Species diversity declines upstream in accordance with these barriers as they restrict upstream migration (Fig. 5.). Anguilla mossambica was the only marine-spawned species able to traverse the Dodd's farm weir located below Site 5. Two M. falciformis were sampled from above this first barrier at Site 4 and all other marine-spawned species were sampled from below Site 4 . For further analysis, sites were grouped into regions based on their location with respect to barriers. The lower region (Sites 1-3) was free of migration barriers and was most dissimilar to the regions above any subsequent barriers. Much of this dissimilarity was attributed to the variable abundance of $B$. pallidus, $P$. philander and $T$. sparrmanii and not to the presence of marine migrants, presumably due to their low relative abundance. Excluding the two alien species from the analysis revealed the impact of instream barriers on the indigenous fish fauna. SIMPER analysis revealed that the lower, barrier-free, region was greatly dissimilar (89.2\%) from the sample sites above the first weir. Barbus pallidus, M. capensis and M. falciformis contributed uniformly to this site dissimilarity with 24,20 and $20 \%$, respectively. Barbus pallidus, being the most abundant remaining species, contributed disproportionately to the site dissimilarity among all other regions. A cluster analysis using native fish species illustrates this site dissimilarity between the barrierfree lower region and all other upstream regions (Fig. 6) which are not greatly dissimilar. The absence of marine migrants at sampling sites above the first barrier is the primary contributor to this site dissimilarity.

\section{DISCUSSION}

The canalisation of the lower Baakens River has altered the historic estuarine area. Currently there is minimal marine water intrusion into the lower river, thus the estuary region is confined to a narrow outlet which opens into the Port Elizabeth harbour. Nevertheless, the freshwater outflow still appears to act as a cue to marine migrants as a number of marinespawned species were sampled from the lower regions of the river. Physico-chemical variables showed little variation among sites and, as a result there was no significant relationship between the abundance, distribution and community composition of fishes and the physico-chemical environment of sampling sites. This is consistent with observations that in regulated rivers, physico-chemical variables have little influence on structuring of fish assemblages when compared to the effects 


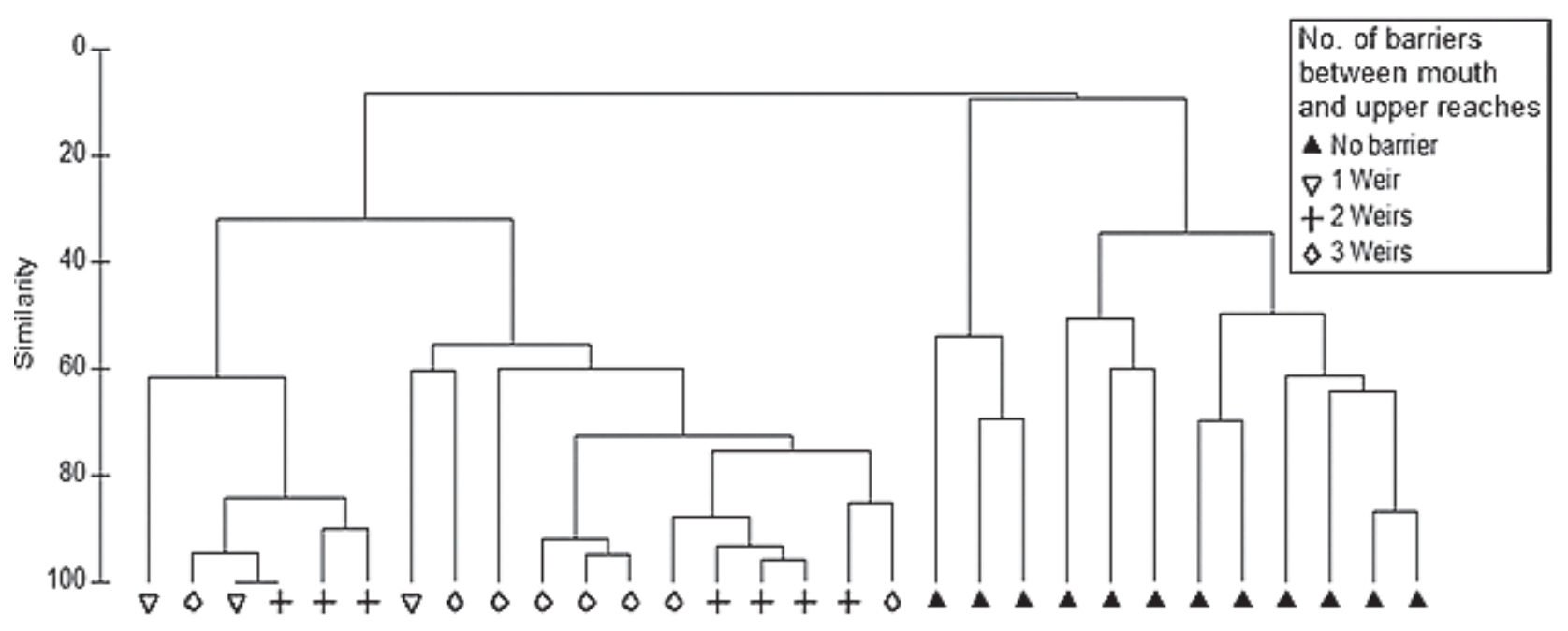

Figure 6

Bray-Curtis dendrogram showing percentage similarity of areas separated by instream barriers measured by density of marine spawned and freshwater species excluding alien species (P. philander and T. sparrmanii)

of habitat complexity (Mattos et al., 2014). River regulation, in terms of barriers, appeared to be a far greater determinant of species composition and distribution in the Baakens River, particularly for migrating fishes of marine origin. Liermann et al. (2012) concluded that, globally, the fragmentation of rivers is considered the primary cause for declines in populations of migratory fish. While locally Wasserman et al. (2011) showed that instream barriers constructed along the length of the Sundays River excluded upstream movement of several migrating marine fish species. As a result, these instream barriers are cutting off the important nursery areas provided by rivers and upper estuaries, which are known to be an important habitat for young estuary-dependent marine species (Wasserman and Strydom, 2011). In the barrier-free Great Kei River, for example, $M$. capensis were recorded $173 \mathrm{~km}$ upstream of the estuary (Bok, 1983), while in the Baakens River not a single M. capensis was captured above the first barrier only $1.4 \mathrm{~km}$ upstream. Bok (1994) also recorded high numbers of Mugil cephalus, which recruit into the Baakens River in winter, as being constrained by this barrier. The absence of marine migrant species, apart from A. mossambica, from sample sites above the first barrier illustrates the impact of weirs on the upstream migration of these species. Man-made barriers in the form of dams, weirs, barrages or road crossings are putting potentially large areas of habitat out of reach of marine migrant species, which have evolved life-history strategies to take advantage of these relatively protected, food-rich habitats (Bok, 1979; Fausch et al., 2002). Barriers also affect freshwater species by fragmenting the natural river course and even small weirs can reduce gene flow and negatively impact on the genetic structure of fish populations (Blanchet et al., 2010).

Of the three native freshwater fishes sampled during this survey, B. pallidus and S. capensis are widespread and abundant (see Table 2 and Fig. 4) while P. afer abundance was low and its distribution restricted to a single site (Site 4) during the current survey. Pseudobarbus afer is IUCN Red-Listed as endangered (see Weyl et al., 2014) and the Baakens River is one of the last few known refuges for the geographically-restricted 'Mandela genetic lineage' of this species (Swartz et al., 2007).

From the current study and the historical comparison of electrofishing surveys presented by Muller et al. (2015), it is evident that the Baakens River has undergone considerable changes with regard to species composition since surveys in the early 1990s (Bok, 1994) with a now overwhelming dominance of the alien $P$. philander. Alien fishes have been shown to impact on native fish communities through predation and by competition (see Ellender and Weyl, 2014). For example, largemouth bass Micropterus salmoides were shown to prey on migrating estuarine and marine fishes in the Kowie River (Weyl and Lewis, 2006). With regard to competition, Alexander et al. (2015) demonstrated that invasive fishes typically exhibited higher functional responses, characterised by higher prey attack and consumption rates and lower prey handling times than native fishes. Such competitive interactions among similar-sized native and alien species can lead to the extirpation of the native species (Mills et al., 2004).

\section{CONCLUSION}

In the Baakens River, human activities, in the form of habitat alteration, pollution from sewage and species introductions, appear to have altered the fish assemblage over time (see Muller et al., 2015). Instream barriers and canalisation limit fish migration putting the safety and feeding opportunities of much of the river out of reach for many marine-spawned species, such as the catadromous mugilid, M. capensis. In addition, the introduction of alien fishes is likely to have negative impacts on native fishes (Ellender and Weyl, 2014). Alteration of river habitats and the introduction of alien species are common problems in many South African rivers. This not only affects indigenous biodiversity but also results in the increased homogenization of landscapes and biota across the country (Scott and Helfman, 2001). Of particular concern is the low abundance and narrow distribution of $P$. afer, an endangered species, in the Baakens River.

\section{ACKNOWLEDGMENTS}

The research was funded by the National Research Foundation, South Africa (NRF, UID: 77444 [OLFW] and 79733 [NAS]) and the DST/NRF Centre of Excellence for Invasion Biology (CM and OLFW). The authors extend their sincere thanks to the Conservation Education Officer of Settlers Park, especially 
Mr Clyde Scott, for providing logistical support to collect samples; Mr Morgen Griffiths of WESSA for providing background information to the Baakens River; and Jonathan Botha for valued field assistance. The Eastern Cape Department of Economic Development and Environmental Affairs (DEDEA) is thanked for issuing research permits.

\section{REFERENCES}

ALEXANDER ME, DICK JT, WEYL OLF, ROBINSON TB and RICHARDSON DM (2014) Existing and emerging high impact invasive species are characterized by higher functional responses than natives. Biol. Lett. 10 (2) DOI: 10.1098/rsbl.2013.0946.

BLANCHET S, REY O, ETIENNE R, LEK S and LOOT G (2010) Species-specific responses to landscape fragmentation: implications for management strategies Evol. Appl. 3 (3) 291-304.

BOK A (1979) The distribution and ecology of two mullet species in some fresh water rivers in the eastern Cape, South Africa. J. Limnol. Soc. Southern Afr. 5 (2) 97-102.

BOK A (1984) The demography, breeding biology and management of two mullet species (Pisces: Mugilidae) in the eastern Cape, South Africa. Ph.D thesis, Rhodes University, Grahamstown.

BOK A (1994) Report on a fish survey of the Baakens River: December 1994. Eastern Cape Nature Conservation, Port Elizabeth.

BOK A (1997) Necessity for and conceptual design of fishways in the Baakens River, Settlers Park. Anton Bok and Associates, Port Elizabeth.

DARWALL, W, TWEDDLE D and SKELTON P (2009) The Status and Distribution of Freshwater Biodiversity in Southern Africa. IUCN and SAIAB, Gland, Switzerland and Grahamstown, South Africa.

ELLENDER BR and WEYL OLF (2014) A review of current knowledge, risk and ecological impacts associated with non-native freshwater fish introductions in South Africa. Aquat. Invasions 9 (2) 117-132.

FAUSCH KD, TORGERSEN CE, BAXTER CV and LI HW (2002) Landscapes to riverscapes: bridging the gap between research and conservation of stream fishes a continuous view of the river is needed to understand how processes interacting among scales set the context for stream fishes and their habitat. BioScience 52 (6) 483-498.

GEERAERTS C, OVIDIO M, VERBIEST H, BUYSSE D, COECK J, BELPAIRE C and PHILIPPART JC (2007) Mobility of individual roach Rutilus rutilus (L.) in three weir-fragmented Belgian rivers. Hydrobiologia 582 143-153.

LEAR M (2013) The Baakens Valley: An ecological and historical field guide ( $3^{\text {rd }}$ edn). Baakens Valley Community Partnership, Port Elizabeth.

LIERMANN CR, NILSSON C, ROBERTSON J and NG RY (2012) Implications of dam obstruction for global freshwater fish diversity. BioScience 62 (6) 539-548.

MASTERS JE, JANG MH, HA K, BIRD P, FREAR P and LUCAS M (2006) The commercial exploitation of a protected anadromous species, the river lamprey (Lampetra fluviatilis (L.)), in the tidal River Ouse, north-east England. Aquat. Conserv. Mar. Freshwater Ecosyst. 16 (1) 77-92.
MATTOS TM, COSTA MR, PINTO BCT, BORGES JLC and ARAUJO FG (2014) To what extent are the fish compositions of a regulated river related to physico-chemical variables and habitat structure? Environ. Biol. Fishes 97 (6) 717-730.

MILLS MD, RADER RB and BELK MC (2004) Complex interactions between native and invasive fish: the simultaneous effects of multiple negative interactions. Oceologia 141 713-721.

MUKHEIBIR P and SPARKS D (2003) Water resource management and climate change in South Africa: visions, driving factors and sustainable development indicators. Report for Phase I of the Sustainable Development and Climate Change project. Energy and Development Research Centre (EDRC), University of Cape Town.

MULLER C, WEYL OLF and STRYDOM NA (2015) Introduction, establishment and spread of the Southern mouthbrooder Pseudocrenilabrus philander in the Baakens River, Eastern Cape, South Africa. Afr. Zool. 50 (3) 259-262.

NEL J, DRIVER A, STRYDOM W, MAHERRY A, PETERSEN C, HILL L, ROUX D, NIENABER S, VAN DEVENTER H and SWARTZ E (2011) Atlas of freshwater ecosystem priority areas in South Africa. WRC Report No. TT 500/11. Water Research Commission, Pretoria.

PLUMSTEAD E (1990) Changes in ichthyofaunal diversity and abundance within the Mbashe estuary, Transkei, following construction of a river barrage. S. Afr. J. Mar. Sci. 9 (1) 399-407.

SCOTT MC and HELFMAN GS (2001) Native invasions, homogenization, and the mismeasure of integrity of fish assemblages. Fisheries 26 (11) 6-15.

SKELTON PH, CAMBRAY JA, LOMBARD A and BENN GA (1995) Patterns of distribution and conservation status of freshwater fishes in South Africa. S. Afr. J. Zool. 30 (3) 71-81.

SWARTZ ER, SKELTON PH and BLOOMER P (2007) Sea-level changes, river capture and the evolution of populations of the Eastern Cape and fiery redfins (Pseudobarbus afer and Pseudobarbus phlegethon, Cyprinidae) across multiple river systems in South Africa. J. Biogeogr. 34 (12) 2086-2099.

WASSERMAN RJ and STRYDOM NA (2011) The importance of estuary head waters as nursery areas for young estuary- and marinespawned fishes in temperate South Africa. Estuar. Coast. Shelf Sci. 94 (1) $56-67$.

WASSERMAN RJ, WEYL OLF and STRYDOM NA (2011) The effects of instream barriers on the distribution of migratory marinespawned fishes in the lower reaches of the Sundays River, South Africa. Water SA 37 (4) 495-504.

WEYL OLF, FINLAYSON B, IMPSON ND, WOODFORD DJ and STEINKJER J (2014) Threatened endemic fishes in South Africa's Cape Floristic Region: a new beginning for the Rondegat River. Fisheries 39 (6) 270-279.

WEYL OLF and LEWIS H (2006) First record of predation by the alien invasive freshwater fish Micropterus salmoides L.(Centrarchidae) on migrating estuarine fishes in South Africa. Afr. Zool. 41 (2) 294-296. 